\title{
Urothelial (Transitional Cell) Carcinoma of the Prostate pT3 TNM Finding v7
}

National Cancer Institute

\section{Source}

National Cancer Institute. Urothelial (Transitional Cell) Carcinoma of the Prostate pT3

TNM Finding v7. NCI Thesaurus. Code $C 89383$.

Urothelial (transitional cell) carcinoma of the prostate with tumor invading any of the following: corpus cavernosum, beyond prostatic capsule, bladder neck (extraprostatic extension). (from AJCC 7th Ed.) 